\title{
Plasma lipids, blood coagulation and fibrinolysis in peripheral arterial disease
}

\author{
R. G. NeWALL* \\ F.I.S.T.
}

\author{
B. P. BLISS \\ M.S., F.R.C.S.
}

\author{
C. J. C. KIRK \\ F.I.M.L.T.

\section{Department of Surgery, Charing Cross Hospital Medical School, London}

\section{Summary}

In a study relating platelet stickiness, plasma fibrinogen and fibrinolysis to fasting plasma lipids in patients with atherosclerosis of the lower limbs, a significant correlation has been observed between platelet stickiness and plasma phospholipid levels. The possible mechanisms are discussed. No other correlation is observed. Fasting levels of plasma fibrinogen were raised, while levels of plasminogen, and the degree of platelet stickiness in many cases were normal.

\section{Introduction}

The clinical features of peripheral arterial disease result from a combination of atherosclerosis in the limb arteries and thrombosis within their lumina. In some cases the symptoms are predominantly due to atherosclerosis, and in others thrombosis is the dominant lesion.

Abnormalities of plasma lipids and lipoproteins are common in association with atherosclerosis in these patients, and may have some causal relationship (Wahlberg, 1962; Newall, 1971; Bliss, Kirk \& Newall, 1972; Greenhalgh et al., 1971).

Since arterial thrombosis is common in these cases, many investigations have sought evidence for either increased intravascular coagulation or decreased fibrinolysis. The evidence from these investigations is confused, some authors reporting a predisposition to thrombotic events, others finding only normal values (McDonald \& Edgill, 1957; Katz et al., 1963; Eastham, 1964b; Kirby \& Martin, 1966; Ashton et al., 1967).

* Present address and requests for reprints: Alexander Simpson Laboratory for Metabolic Research, St Mary's Hospital Medical School, London W.2.
It seemed of interest to investigate some of the parameters of blood coagulation and fibrinolysis, and relate these to the abnormalities in plasma lipids we have previously reported (Bliss et al., 1972). The levels of platelet stickiness, fibrinogen and plasminogen have been measured in males suffering from atherosclerotic peripheral arterial disease. Any relationships between these and the levels of the fasting plasma lipids have been examined.

\section{Subjects and conditions}

The subjects comprised thirty-six males, aged 40-70 years, suffering from clinical manifestations of atherosclerosis of the lower limbs. Blood samples were withdrawn after a 12-14-hr overnight fast, during which time the patients were requested to refrain from smoking. No patient had received treatment prior to investigation.

Plasma triglycerides were measured as glyceride glycerol, according to Lofland (1964). Triglyceride concentration $=$ glyceride glycerol $\times 9 \cdot 62$. Total cholesterol was measured by the automated method of Block, Jarrett \& Levine (1966). Plasma phospholipids were assayed using the combined methods of Connerty, Briggs \& Eaton (1961) and Gomori (1942). Platelet stickiness was measured by the method of Eastham (1964a); fibrinogen by the method of Lempert (1967); and plasminogen by the caseinolytic method of Alkjaersig, Fletcher \& Sherry (1959).

\section{Results}

The mean fasting values of all the parameters being studied are presented in Table 1 . The fasting levels of glyceride glycerol and fibrinogen are elevated; other parameters are within the normal range.

TABLE 1. Fasting values and normal limits

\begin{tabular}{cccccc}
\hline $\begin{array}{c}\text { Cholesterol } \\
(\mathrm{mg} / 100 \mathrm{ml})\end{array}$ & $\begin{array}{c}\text { Glyceride glycerol } \\
(\mathrm{mg} / 100 \mathrm{ml})\end{array}$ & $\begin{array}{c}\text { Phospholipid } \\
(\mathrm{mg} / 100 \mathrm{ml})\end{array}$ & $\begin{array}{c}\text { Platelet stickiness } \\
(\%)\end{array}$ & $\begin{array}{c}\text { Fibrinogen } \\
(\mathrm{mg} / 100 \mathrm{ml})\end{array}$ & $\begin{array}{c}\text { Plasminogen } \\
(\mathrm{U} / \mathrm{ml})\end{array}$ \\
\hline $\begin{array}{c}248 \\
\mathrm{SD} \pm 94\end{array}$ & $\begin{array}{c}22 \cdot 1 \\
\pm 14 \cdot 4\end{array}$ & 228 & $48 \cdot 8$ & 477 \\
\pm 67 & $\pm 17 \cdot 1$ & $4 \cdot 1$ \\
$\pm 1 \cdot 2$ \\
$\begin{array}{c}\text { Upper limit of normal: } \\
270\end{array}$
\end{tabular}

* Using methods of Eastham (1964a), Hellem (1960) and Salzman (1963). 
TABLE 2. Comparison of blood factors and plasma lipids

\begin{tabular}{lcc}
\hline \multicolumn{1}{c}{ Comparison of: } & $\begin{array}{c}\text { Correlation } \\
\text { Coefficient } \\
(r)\end{array}$ & $\begin{array}{c}\text { Probability } \\
(P)\end{array}$ \\
\hline Platelet stickiness and cholesterol & 0.319 & $<0.1$ \\
Platelet stickiness and phospholipid & 0.492 & $<0.01$ \\
Platelet stickiness and glyceride glycerol & 0.082 & $>0 \cdot 1$ \\
Platelet stickiness and fibrinogen & $0 \cdot 144$ & $>0 \cdot 1$ \\
Platelet stickiness and plasminogen & 0.125 & $>0 \cdot 1$ \\
Cholesterol and phospholipid & 0.411 & $<0.02$ \\
Cholesterol and glyceride glycerol & 0.618 & $<0.001$ \\
Cholesterol and fibrinogen & 0.06 & $>0.1$ \\
Cholesterol and plasminogen & 0.283 & $<0.01$ \\
Phospholipid and glyceride glycerol & 0.546 & $>0 \cdot 1$ \\
Phospholipid and fibrinogen & 0.095 & $>0.1$ \\
Phospholipid and plasminogen & 0.075 & $>0.1$ \\
Glyceride glycerol and fibrinogen & 0.117 & $>0.1$ \\
Glyceride glycerol and plasminogen & 0.016 & $>0.1$ \\
Fibrinogen and plasminogen & 0.084 & \\
\hline
\end{tabular}

Pairs of the parameters being studied are compared, and the correlation coefficient $(r)$ and the probability $(P)$ are calculated for each pair to determine whether any relationship exists. The results are presented in Table 2.

\section{Comparison of blood factors and plasma lipids}

Correlation is observed between platelet stickiness and plasma phospholipids. Correlation is also observed, as expected, between the basic constituents of the lipoproteins-cholesterol, triglyceride (as glyceride glycerol) and phospholipid. No other correlations were observed.

\section{Discussion}

\section{Fasting levels}

(a) Platelet stickiness. In the disease group, the degree of platelet stickiness of $48.8 \%$ is not high (Table 1) and compares well with the value obtained by Sjögren et al. (1970) of $44.6 \%$, using the similar method of Hellem (1960). However, the high standard deviation shows that some patients exhibit abnormal values.

Different methods of estimation often give widely different results, and caution must be shown in comparing results (Mustard \& Packham, 1967; Cronberg, 1967). In a later paper, on subjects with ischaemic heart disease Sjögren et al. (1971) obtained values for platelet adhesion of $29.7 \%$ using the method of Wright (1941) and $47 \cdot 3 \%$ using Salzman's method (Salzman, 1963). Results for age-matched controls were very slightly lower than for the patients. Using Eastham's method (1964a), a value of $48.7 \%$ falls within the normal range.

(b) Fibrinogen. The generally accepted normal range for plasma fibrinogen levels is $200-400 \mathrm{mg} /$ $100 \mathrm{ml}$. The observed mean value of $477 \mathrm{mg} / 100 \mathrm{ml}$ for the patients indicates a raised level of fibrinogen in these cases. This is in agreement with the observations of Katz et al. (1963).

(c) Plasminogen. The generally accepted normal range for plasminogen levels in $2 \cdot 5-6$ units $/ \mathrm{ml}$. The disease group has a mean plasminogen level of $4 \cdot 1$ units $/ \mathrm{ml}$ with a low standard deviation. This is a normal value, and suggest that no abnormality of fibrinolysis is present in our patients suffering from peripheral arterial disease. This is consistent with the findings of Katz et al. (1963).

Correlation between blood coagulation and fibrinolysis and fasting plasma lipids

The only significant correlation of note is observed between platelet stickiness and plasma phospholipids, although this is only at the $1 \%$ level. Bolton, Hampton \& Mitchell (1967) found an abnormality in platelet behaviour in patients with peripheral arterial disease and ischaemic heart disease. This abnormality is determined by the concentration of adenosine diphosphate (ADP) required to cause a maximum increase in platelet electrophoretic mobility. This sensitivity was found to be due to a 'transferable factor' in the plasma, consisting of a stable low-density lipoprotein with lecithin as the active principle, and a labile phospholipase enzyme converting lecithin to lysolecithin. The authors conclude that lysolecithin is probably the cause of the abnormal platelet behaviour. This could well explain the observed correlation between platelet stickiness and plasma phospholipids. This abnormal platelet behaviour has also been found in cases of multiple sclerosis (Bolton, Hampton \& Phillipson, 1968).

In a recent publication, Besterman \& Gillett (1971), have demonstrated an inhibition of platelet aggregation by lysolecithin. However, this effect is dose-dependent, and the lysolecithin concentration 
required for inhibition is far in excess of physiological levels.

Bloom \& Evans (1969) have shown an inverse relationship between plasma fibrinogen levels and platelet aggregation. In the present investigations a slight negative correlation was observed but no degree of significance was achieved (Table 2). Inverse relationships have also been reported between fibrinolytic activity and plasma triglycerides (Sweet, Rifkind \& McNicol, 1966). Grace \& Goldrick (1968) have reported this relationship in obese subjects, but when the effects of obesity are taken into account, their results are not significant. Neither a positive nor a negative relationship could be demonstrated in the present study.

The results obtained may well depend on the choice of methods used for the analysis of plasminogen, and of triglycerides.

The observed correlations between the lipids (cholesterol, triglycerides and phospholipids) are to be expected, as all are basic constitutents of the lipoproteins which maintain a relatively constant general composition, although these correlations are not as high as might be anticipated.

\section{Acknowledgments}

Thanks are due to Miss Leah Delage for her skilled technical assistance. The study was supported in part by a grant kindly donated by the West London Hospital Medical Trust: Dan Mason Research Foundation.

\section{References}

Alkaersig, N., Fletcher, A.P. \& Sherry, S. (1959) The mechanism of clot dissolution by plasmin. Journal of Clinical Investigation, 38, 1086.

Ashton, W.L., Pegrum, G., Shaw, S. \& Wolff, S. (1967) In: Human Atheroma (Ed. by W. L. Ashton). Heinemann, London.

Besterman, E.M.M. \& Gillett, M.P.T. (1971) Inhibition of platelet aggregation by lysolecithin. Atherosclerosis, 14, 323.

Bliss, B.P., KIRK, C.J.C. \& Newall, R.G. (1972) Abnormalities in glucose tolerance, lipid and lipoprotein levels in patients with atherosclerotic peripheral arterial disease. Angiology, 23, 69.

Block, W., JARrett, K. \& Levine, J. (1966) An improved automated determination of serum total cholesterol with a single color reagent. Clinical Chemistry, 12, 681 .

Bloom, A.L. \& Evans, E.P. (1969) Plasma fibrinogen and the aggregation of platelets by ADP. Lancet, i, 349.

Bolton, C.H., Hampton, J.R. \& Mitchell, J.R.A. (1967) Nature of the transferable factor which causes abnormal platelet behaviour in vascular disease. Lancet, ii, 1101.

Bolton, C.H., Hampton, J.R. \& Phillipson, O.T. (1968) Platelet behaviour and plasma phospholipids in multiple sclerosis. Lancet, i, 99.

Connerty, R.V., Briggs, A.R. \& Eaton, E.H. (1961) Simplified determination of the lipid components of blood serum. Clinical Chemistry, 7, 37.
Cronberg, S. (1967) Methodological problems in the testing of platelet adhesiveness. Scandinavian Journal of Haemato$\log y, 4,385$.

EASTHAM, R.D. (1963) Rapid whole-blood platelet counting using an electronic particle counter. Journal of Clinical Pathology, 16, 168.

EASTHAM, R.D. (1964) Rapid adhesive platelet count in whole blood. Journal of Clinical Pathology, 17, 45.

Eastham, R.D. (1964) Attempted reduction of adhesive platelets after cardiac infarction. Lancet, ii, 541 .

GoMORI, G. (1942) Modification of the colorimetric phosphorus determination for use with a photoelectric colorimeter. Journal of Laboratory and Clinical Medicine, 27, 955.

GRACE, C.S. \& GoldRICK, R.B. (1968) Fibrinolysis and body build. Interrelationships between blood fibrinolysis, body composition and parameters of lipid and carbohydrate metabolism. Journal of Atherosclerosis Research, 8, 705.

Greenhalgh, R.M., Lewis, B.R., Osengarten, D.S., Calnan, J.S., Mervart, I. \& Martin, P. (1971) Serum lipids and lipoproteins in peripheral muscular disease. Lancet, ii, 947.

Hellem, A.J. (1960) The adhesiveness of human blood platelets in vitro. Scandinavian Journal of Clinical and Laboratory Investigations, 12, Suppl. 51.

Katz, A.H., McDonald, L., Davies, B. \& Edgill, M. (1963) Fibrinolysis and blood coagulation in ischaemic heart disease. Lancet, i, 801.

KirbY, J.C. \& MARTin, C.L. (1966) Platelet adhesiveness and vascular disease. Circulation, Suppl. 3, 17.

Lempert, H. (1967) In: Practical Clinical Chemistry (by H. Varley). Heinemann, London.

LoflaND, H.B. (1964) A semi-automated method for determination of triglycerides in serum. Analytical Biochemistry, 9, 393.

McDonald, L. \& Edgill, M. (1957) Coagulability of the blood in ischaemic heart disease. Lancet, ii, 457.

Mustard, J.F. \& Packham, M.A. (1967) The assessment of platelet adherence. Journal of Atherosclerosis Research, 17, 405.

Newall, R.G. (1971) A lipid and lipoprotein study of patients with peripheral arterial disease, using microenphelometry. Clinica chimica acta, 32, 185.

Saltzman, E. (1963) Measurement of platelet adhesiveness. A simple in vitro technique demonstrating an abnormality in von Willebrand's disease. Journal of Laboratory and Clinical Medicine, 62, 724.

SJögren, A., BotTiger, L.D., BiorCK, G., WAHLberg, F. \& CARlson, L.A. (1970) ADP-induced platelet adhesiveness in patients with ischaemic heart disease. Acta medica scandinavica, 187, 89.

Suögren, A., Bottiger, L.E., Biorck, G., PaAsikiri, J. \& CARLsON, L.A. (1971) Platelet adhesiveness in patients with ischaemic heart disease. An assessment by three wholeblood methods. Acta medica scandinavica, 189, 555.

Sweet, B., Rifkind, B.M. \& McNicol, G.P. (1966) The relationship between lipids and the fibrinolytic enzyme system. Journal of Atherosclerosis Research, 6, 359.

WAHLBERG, F. (1962) The intravenous glucose tolerance test in atherosclerotic disease with special reference to obesity, hypertension, diabetic heredity and cholesterol values. Acta medica scandinavica, 171, 1 .

WRIGHT, H.P. (1941) Adhesiveness of blood platelets in normal subjects with varying concentrations of anticoagulants. Journal of Pathological Bacteriology, 53, 255. 